\section{Low carbohydrate high fat diets: when models do not match reality}

Rennan de Oliveira Caminhotto', Fabio Bessa Lima'

Dear Editor,

$\mathrm{E}$ xperimental science depends on models, especially basic biological research, where animal models can lead us to the comprehension of several phenomena that otherwise would be hardly accessible in humans. By definition, a model is a simplification of a system which is assumed similar to the one being represented. However, every model has limitations due to the difficulty of including all aspects of the reality that is intended to be reproduced.

Animal models on low carbohydrate high fat (LCHF) diets are a good example of these limitations. Although different kinds of LCHF has been associated with good results in human clinical trials $(1,2)$, especially in insulin resistance subjects $(3,4)$, animal models not always reproduce the same beneficial effects, as we could see in Lamont and cols. (5), who recently publish in Nutrition \& Diabetes, which induced fat mass gain and glucose intolerance in pre-diabetic New Zealand Obese (NZO) mice through their submission to LCHF diet.

The effects of LCHF diet in murine models are inconsistent and dependent on several variables, from the animal model used up to changes in experimental diets. For example: Diet induced obesity has already been reversed with a ketogenic LCHF diet in mice (6), while LCHF induced weight gain in Lamont and cols. (5) or has not affected weight of ob/ob mice, although prevented the progression of hepatic steatosis (7). Still, others describe hepatic steatosis in mice after administration of the same diet (8). In addition, the deficiency of choline (a B-complex vitamin) in the commercial LCHF diet used has been pointed as a cause of hepatic mitochondrial dysfunction and fat accumulation found in these LCHF feed mice, instead the macronutrient proportion (9).

As far as we could see, Lamont and cols. (5) used an own LCFH diet, and were careful about micronutrients contain (including choline). On the other hand, sucrose content $(10 \%)$ was one among other differences used in diets (as Bio-Serv F3666 diet which is carbohydrate/sucrose free) and was likely added to improve palatability and acceptance of the diet. We don't know how and how much this detail may have impacted on the effects of LCHF diet in NZO mice, especially considering their hyperphagic behavior, probably due to leptin resistance and hyperinsulinemia during early age (10).

Likewise, it seems that these endocrine features of NZO (Leptin resistance and hyperinsulinemia) are inevitable, different of human obesity and type II diabetes, or others animal models, where a decrease of both hormones and increased satiety are induce by LCHF diet and may be an important part beneficial effects found $(11,12)$.

In short, considering the limitations present in different experimental models and the beneficial results reported by clinical trials (1-4), in our opinion LCHF diets are still an accessible and encouraged option of non-pharmacological intervention for hu-
Departamento de Fisiologia e Biofísica, Instituto de Ciências Biomédicas, Universidade de São Paulo (ICB-USP) São Paulo, SP, Brasil

Correspondence to:

Rennan de Oliveira Caminhotto Departamento de Fisiologia e Biofísica, Instituto de Ciências Biomédicas Universidade de São Paulo Av. Prof. Lineu Prestes, 1524, Ed. Biomédicas I, sala 131 05508-900 - São Paulo, SP, Brasil rennanoc@icb.usp.br

Received on Mar/23/2016 Accepted on Apr/11/2016 DOI: 10.1590/2359-3997000000177 
man metabolic syndrome. All of this shows how careful we must be to transpose basic research findings to clinical care.

Grant: Fundação de Amparo à Pesquisa do Estado de São Paulo (Fapesp), 14/10705-4.

Disclosure: no potential conflict of interest relevant to this article was reported.

\section{REFERENCES}

1. Santos FL, Esteves SS, da Costa Pereira A, Yancy WS Jr, Nunes JP. Systematic review and meta-analysis of clinical trials of the effects of low carbohydrate diets on cardiovascular risk factors. Obes Rev. 2012;13(11):1048-66.

2. Hu T, Mills KT, Yao L, Demanelis K, Eloustaz M, Yancy WS Jr, et al. Effects of low-carbohydrate diets versus low-fat diets on metabolic risk factors: a meta-analysis of randomized controlled clinical trials. Am J Epidemiol. 2012;176 Suppl 7:S44-54.

3. Cornier MA, Donahoo WT, Pereira R, Gurevich I, Westergren R, Enerback $S$, et al. Insulin sensitivity determines the effectiveness of dietary macronutrient composition on weight loss in obese women. Obes Res. 2005;13(4):703-9.

4. Ajala O, English P, Pinkney J. Systematic review and meta-analysis of different dietary approaches to the management of type 2 diabetes. Am J Clin Nutr. 2013;97:505-16.
5. Lamont BJ, Waters MF, Andrikopoulos S. A low-carbohydrate high-fat diet increases weight gain and does not improve glucose tolerance, insulin secretion or $\beta$-cell mass in NZO mice. Nutr Diabetes. 2016;6:e194.

6. Kennedy AR, Pissios P, Otu H, Roberson R, Xue B, Asakura K, et al. A high-fat, ketogenic diet induces a unique metabolic state in mice. Am J Physiol Endocrinol Metab. 2007;292(6):E1724-39.

7. Okuda T, Morita N. A very low carbohydrate ketogenic diet prevents the progression of hepatic steatosis caused by hyperglycemia in a juvenile obese mouse model. Nutr Diabetes. 2012;2:e50.

8. Garbow JR, Doherty JM, Schugar RC, Travers S, Weber ML, Wentz $A E$, et al. Hepatic steatosis, inflammation, and $E R$ stress in mice maintained long term on a very low-carbohydrate ketogenic diet. Am J Physiol Gastrointest Liver Physiol. 2011;300(6): G956-67.

9. Schugar RC, Huang X, Moll AR, Brunt EM, Crawford PA. Role of choline deficiency in the Fatty liver phenotype of mice fed a low protein, very low carbohydrate ketogenic diet. PLoS One. 2013;8(8):e74806.

10. King AJ. The use of animal models in diabetes research. $\mathrm{Br} \mathrm{J}$ Pharmacol. 2012;166(3):877-94.

11. Ratliff J, Mutungi G, Puglisi MJ, Volek JS, Fernandez ML. Carbohydrate restriction (with or without additional dietary cholesterol provided by eggs) reduces insulin resistance and plasma leptin without modifying appetite hormones in adult men. Nutr Res. 2009;29(4):262-8.

12. Volek JS, Sharman MJ, Love DM, Avery NG, Gómez AL, Scheett TP, et al. Body composition and hormonal responses to a carbohydrate-restricted diet. Metabolism. 2002;51(7):864-70. 